\title{
In vitro Study on the Mechanism of Ammonium Chloride on the Prevention of Urolithiasis in Fattening Cattle
}

\author{
Hideo Yano and Ryoji Kawashima \\ Department of Animal Science, Kyoto University, Kyoto-shi 606 \\ (Received June 19, 1975)
}

\begin{abstract}
The mechanism of ammonium chloride on the prevention of urolithiasis in fattening cattle was examined in vitro through the solubility of magnesium phosphate and magnesium ammonium phosphate in tris-maleate buffer solution. Tw ograms of magnesium phosphate or magnesium ammonium phosphate were added to $300 \mathrm{ml}$ aliquots of buffer solution in tightly stoppered flasks. These flasks were incubated at $39^{\circ} \mathrm{C}$ and were shaken on a mechanical shaker for 6 hours. Samples of $5 \mathrm{~m} l$ were taken from each flask at intervals of $0,1,2,4$ and 6 hours after shaking. When $\mathrm{pH}$ values were decreased in buffer solutions, the solubilities of magnesium phosphate and magnesium ammonium phosphate clearly elevated. Phosphorus concentrations in supernatant liquids tended to be decreased by increasing the calcium concentration in aliquots of buffer solution. It was considered that this result was due to the formation of the complex. of calcium and phosphorus. Only slight increases in the solubilities of magnesium phosphate and magnesium ammonium phosphate were induced by adding sodium salts. In the range from 0 to $200 \mathrm{mg} \%$, and 0 to $600 \mathrm{mg} \%$, the solubilities of magnesium phosphate and magnesium ammonium phosphate tended to decrease while the concentration of ammonium increased. It was suggested from these results that, among the effects of ammonium chloride, the decreasing of urine $\mathrm{pH}$ would play the most important role on the prevention of urolithiasis in fattening cattle.
\end{abstract}

It was indicated that the administration of ammonium chloride had been effective in the prevention of phosphatic urolithiasis in fattening cattle and sheep $\mathrm{p}^{1-4)}$. The previous experiment ${ }^{5 \text { ) }}$ showed that the addition of ammonium chloride to a ration had increased the urine volume and the urine concentrations of calcium, sodium and chloride, and decreased the urine pH value in wethers.

Though the increase of urine volume will be expected to prevent urolithiasis, the relation betwean the changes of urine components and the treatment of urinary calculi is not definitely known. Assuming the changes of urine components, by giving ammonium chloride, these conditions were prepared in vitro.

This experiment was conducted to determine the mechanism of ammonium chloride through the changes of solubilities of magnesium phosphate and magnesium ammonium phosphate in in vitro condition.

\section{Materials and Methods}

In this experiment, the solubilities of magnesium phosphate $\left(\mathrm{MgHPO}_{4} \cdot 3 \mathrm{H}_{2} \mathrm{O}\right)$ and magnesium ammonium phosphate $\left(\mathrm{MgNH}_{4} \mathrm{PO}_{4} \cdot 6 \mathrm{H}_{2} \mathrm{O}\right)$ were examined when $\mathrm{pH}$ values and the levels of calcium, sodium, chloride and ammonium were changed in tris-maleate buffer solutions. Two grams of magnesium phosphate or magnesium ammonium phosphoate were added in $300 \mathrm{ml}$ Jap. J, Zootech. Sci., 46, (11): 649-655. 
aliquots of buffer solution in a tightly stoppered flask. The flask was incubated at $39^{\circ} \mathrm{C}$ and was shaken on a mechanical shaker for 6 hours.

The $\mathrm{pH}$ values of buffer solution were changed approximately $5.5,6.5,7.5,8.5$ and 11.5 through the changes of tris-maleate and sodium hydroxide ratio. Calcium concentrations in buffer solution were varied to $0,10,20,30$ and $40 \mathrm{mg} \%$ by the addition of calcium chloride or calcium carbonate. Sodium concentrations in buffer solution were varied to $0,200,400,600$ and $800 \mathrm{mg}$ $\%$ by the addition of sodium acetate or sodium sulfate. Chloride levels were varied to 0, 200, 400, 600 and $800 \mathrm{mg} \%$ by the addition of sodium chloride. Ammonium levels were varied to $0,200,400,600$ and $800 \mathrm{mg} \%$ by the addition of ammonium sulfate or ammonium chloride.

Except for the trial with $\mathrm{pH}$ changes, $\mathrm{pH}$ values in aliquots of buffer solution were adjusted approximately to 8.0 which was normal urine $\mathrm{pH}$ value in cattle ${ }^{6}$. Samples of $5 \mathrm{~m} l$ were taken from each flask at intervals of $0,1,2,4$, and 6 hours after the beginning of shaking. The pH values were determined in each sample soon after taking samples with a glass rod pH meter. Then these samples were centrifuged at $3000 \mathrm{rpm}$ for 30 minutes, and the concentrations of phosphorus and magnesium in supernatants were determind by the method of Fiske and Subbarow ${ }^{7}$ and by atomic absorption sepctrometer respectively.

\section{Results}

As shown in figure 1-1 and 1-2, the solubilities of magnesium phosphate and magnesium ammonium phosphate were higher in buffer solutions of low $\mathrm{pH}$ than in solutions of high $\mathrm{pH}$. This trend was more obvious in magnesium ammonium phosphate than in magnesium phosphate.

As shown in figure 2, the phosphorus solubility after shaking with magnesium phosphate and magnesium ammonium phosphate tended to be decreased by increasing the calcium concentration. On the other hand, the magnesium solubility appeared to be increased with the elevation of calcium concentration after equilibration with magnesium phosphate. The result of this
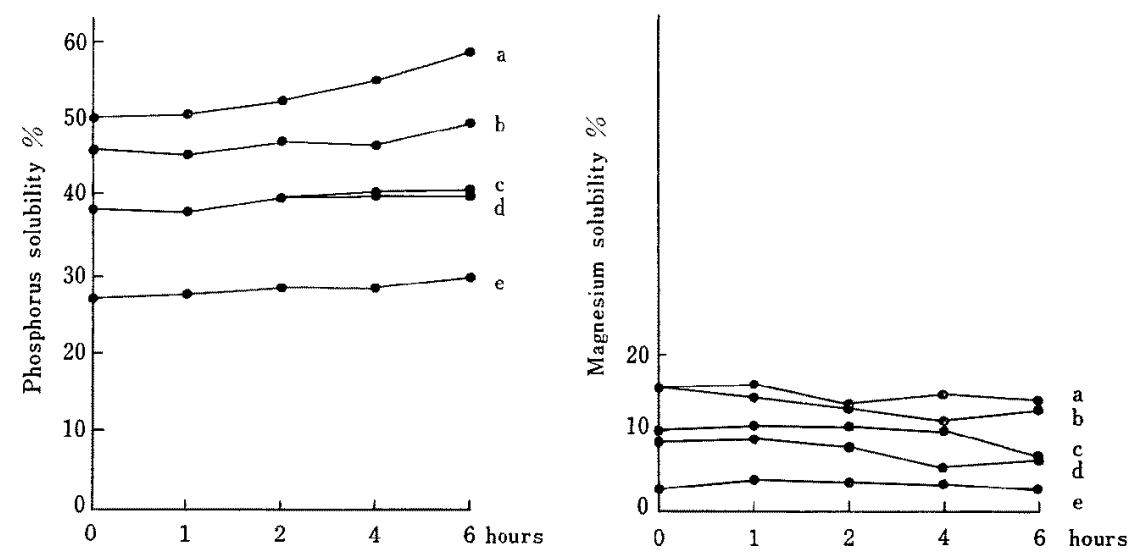

Fig. 1-1. Effect of $\mathrm{pH}$ value upon phosphorus and magnesium solubilities in buffer solutions for 6 hours shaking with $\mathrm{MgHPO}_{4} \cdot 3 \mathrm{H}_{2} \mathrm{O}$. The $\mathrm{pH}$ value in each aliquot: a; 5.5 (before shaking)-5.7 (after 6 hours shaking), b;6.5-6.5, c; 7.5-7.4, d; 8.5-8.4, e; $12.0-11.3$ 
Studies on Urolithiasis
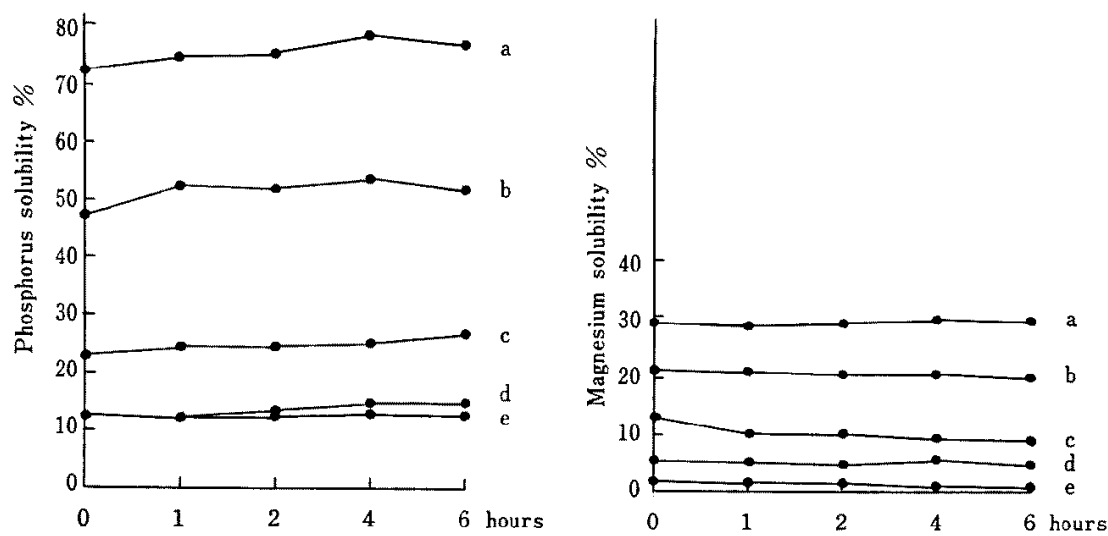

Fig. 1-2. Effect of $\mathrm{pH}$ value upon phosphorus and magnesium solubilities in buffer solutions for 6 hours shaking with $\mathrm{MgNH}_{4} \mathrm{PO}_{4} \cdot 6 \mathrm{H}_{2} \mathrm{O}$. The $\mathrm{pH}$ value in each aliquot: a; 5.4 (before shaking) -6.1 (after 6 hours shaking), b; 6.8-6.8, c; 7.9-7.6, d; 8.9-8.6 e; $11.5-10.9$

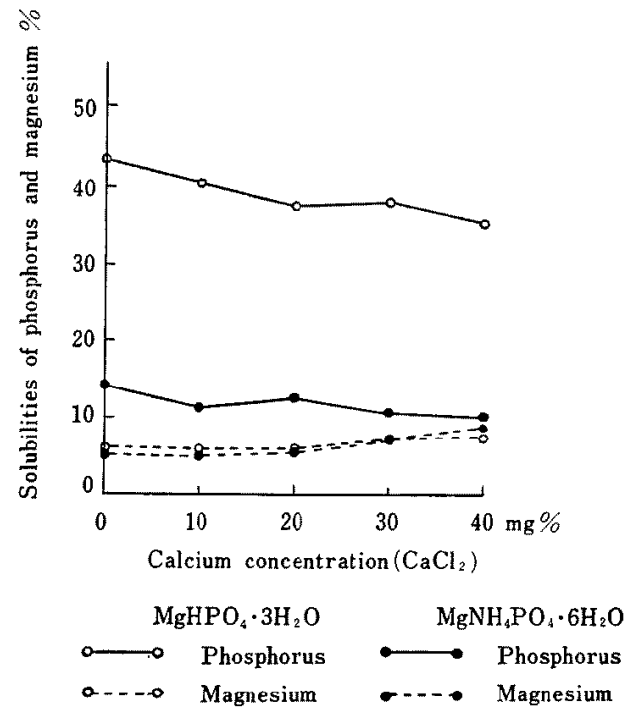

Fig. 2. Effect of calcium concentration upon phosphorus and magnesium solubilities in buffer solutions after 6 hours shaking with $\mathrm{MgHPO}_{4} \cdot 3 \mathrm{H}_{3} \mathrm{O}$ and $\mathrm{MgNH}_{4} \mathrm{PO}_{4} \cdot 6 \mathrm{H}_{2} \mathrm{O}$

trial, which used calcium carbonate as calcium additive, was similar to that which used calcium chloride.

In figure 3, a slight increase in phosphorus solubility was found by adding sodium acetate as sodium salts when equilibrated with magnesium ammonium phosphate. However, there was little change in the solubility of phosphorus equilibrated with magensium phosphate. The effect 


\section{YANO and KAWASHIMA}

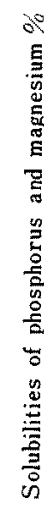

0

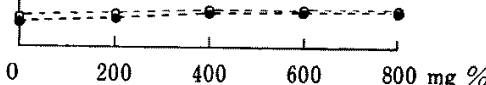

Sodium concentration $\left(\mathrm{CH}_{3} \mathrm{COONa}\right)$

$\mathrm{MgHPO}_{\downarrow} \cdot 3 \mathrm{H}_{2} \mathrm{O}$

$\multimap$ Phosphorus

$\mathrm{MgNH}_{4} \mathrm{PO}_{4} \cdot 6 \mathrm{H}_{2} \mathrm{O}$

a...- Magnesium

..... Magnesium

Fig. 3. Effect of sodium concentration upon phosphorus and magnesium solubilities in buffer solutions after 6 hours shaking with $\mathrm{MgHPO}_{4} \cdot 3 \mathrm{H}_{2} \mathrm{O}$ and $\mathrm{MgNH}_{4} \mathrm{PO}_{4}$. $6 \mathrm{H}_{2} \mathrm{O}$

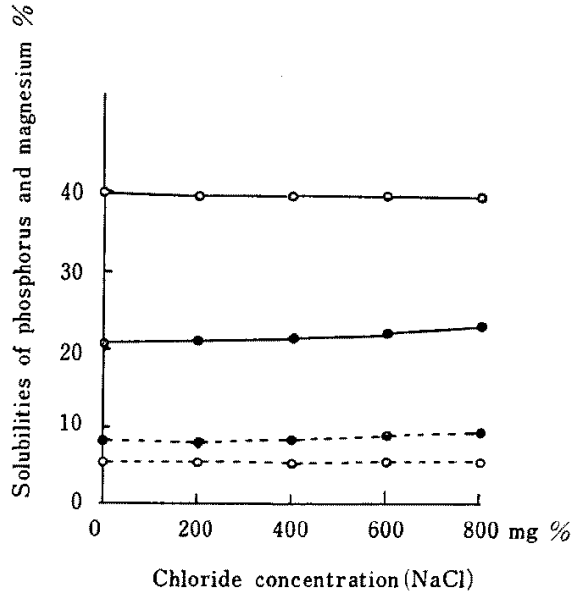

$\mathrm{MgHPO}_{4} \cdot 3 \mathrm{H}_{2} \mathrm{O}$

$\mathrm{MgNH}_{4} \mathrm{PO}_{4} \cdot 6 \mathrm{H}_{2} \mathrm{O}$

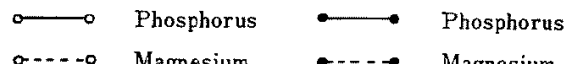

a...- Magnesium $\bullet . .-$ Magnesium

Fig. 4. Effect of chloride concentration upon phosphorus and magnesium solubilities in buffer solutions after 6 hours shaking with $\mathrm{MgHPO}_{4} \cdot 3 \mathrm{H}_{2} \mathrm{O}$ and $\mathrm{MgNH}_{4} \mathrm{PO}_{4}$. $6 \mathrm{H}_{2} \mathrm{O}$

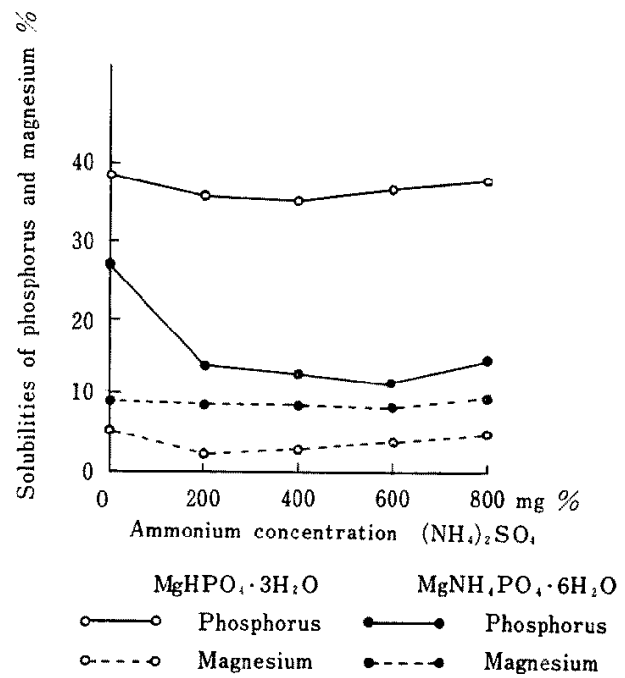

Fig. 5. Effect of ammonium concentration upon phosphorus and magnesium solubilities in buffer solutions after 6 hours shaking with $\mathrm{MgHPO}_{4} \cdot 3 \mathrm{H}_{2} \mathrm{O}$ and $\mathrm{MgNH}_{4} \mathrm{PO}_{4} \cdot 6 \mathrm{H}_{2} \mathrm{O}$ 
of sodium sulfate was similar to that of sodium acetate on the solubilities of magnesium phosphate and magnesium ammonium phosphate.

As shown in figure 4, the increasing of chloride concentration caused only slight increases in phosphorus and magnesium solubilities after equilibration with magnesium ammonium phosphate. And noticeable changes were not found in phosphorus and magnesium solubilities by increasing the chloride concentration in buffer solutions when equilibrated with magnesium phosphate.

The results obtaind by the addition of ammonium salts to aliquots of buffer solution were shown in figure 5.

In the range from 0 to $400 \mathrm{mg} \%$, the phosphorus solubility was decreased slightly and in the range from 400 to $800 \mathrm{mg} \%$ the phosphorus solubility was increased slightly with the elevation of ammonium level after the equilibration with magnesium phosphate. The magnesium solubility was also decreased at the ammonium level of $400 \mathrm{mg} \%$. Likewise, when equilibration with magnesium ammonium phosphate, the phosphorus solubility was decreased in the range from 0 to $600 \mathrm{mg} \%$ with increasing ammonium concentration; this trend was especially evident in the range from 0 to $200 \mathrm{mg} \%$. The magnesium solubility was not so clearly changed with the variation of ammonium level when magnesium ammonium phosphate was used as a substrate.

It was found in all trials that phosphorus more readily dissolved than magnesium. The solubility of phosphorus was substantially higher than magnesium when magnesium phosphate was used as a substrate.

\section{Discussion}

From the results of this experiment, it is evident that a decrease of $\mathrm{pH}$ would increase the solubilities of magnesium phosphate and magnesium ammonium phosphate. This observation is supported by the report of JoHnsos $^{3}$ ? that a decrease of $\mathrm{pH}$ would result in an increase in the capacity of the liquid phase to hold magnesium, phosphate and ammonium in salt solution with equilibrated with solid magnesium ammonium phosphate.

Elurot et al..$^{9)}$ also reported that the solubility of magnesium ammonium phosphate increased with increasing hydrogen ion concentration. As previously reported ${ }^{4}$, urine $\mathrm{pH}$ values were decreased in $\mathrm{pH}$ ranges from 0.8 to 1.4 by the administration of ammonium chloride in wethers. The acidified urine, when given ammonium chloride, seemed to increase the solubility of urinary calculi. This may support the assumption by Bushman et al. ${ }^{2,3)}$ that the mode of action of ammonium chloride would be through a reduction of urine $\mathrm{pH}$ in sheep.

When the calcium concentration increased in buffer solutions, the phosphorus level in supernatant liquid tended to decrease after the equilibration with magnesium phosphate and magnesium ammonium phosphate. ANDREWS et al. ${ }^{10)}$ and BOYCE et al. ${ }^{11)}$ observed the appearance of calcium-phosphate precipitates after the equilibration with calcium and phosphorus in urine. Therefore, the decrease of phosphorus level will be caused by the formation of a complex of calcium and phosphorus in the buffer solution. When urine calcium levels are heightened by giving ammonium chloride, calcium and phosphorus may combine in urine and the decreased urine phosphorus levels may interfere with the formation of phosphatic urinary calculi. However, this protective effect of heightened urine calcium level against urolithiasis would be limited because the changing of solubility of phosphorus when the variation of calcium levels was not so severe. If the urine concentration of calcium and phosphorus are fairly high, then urinary calculi of calcium phosphate type might be formed. However, when a high concentrate ration is 


\section{YaNO and KaWASHMA}

given to cattle and sheep, the urinary calculi of calcium phosphate type will seldom be observed because a urine calcium level is generally very low.

It was observed in this experiment that the solubility of magnesium ammonium phosphate increased slightly as the sodium concentration elevated in buffer solutions. JoHnson et al. ${ }^{8)}$ reported that increasing the concentration of sodium chloride, sodium sulfate and sodium citrate had caused increases of the solubility of magnesium ammonium phosphate through the elevation of ionic strength. Since the increase of the solubility of magnesium ammonium phosphate was slight, the giving of ammonium chloride to the elevated urine sodium level would not correlate with the prevention of phosphatic urolithiasis. This indication is supported by the suggestion of UESAKA et al. ${ }^{3)}$ and UdALL et al. ${ }^{12)}$ that there appeared to be no relationship between the urine sodium level and the occurrence of urolithiasis.

The solubility of magnesium ammonium phosphate appeared to increase slightly by increasing the chloride concentration in buffer solutions. UDALL et al. ${ }^{12,13)}$ postulated that the administration of sodium chloride reduced the occurrence of urolithiasis due to the increased urine chloride ion which caused ion competition around calculi. However, the positive relationship between the solubilities of magnesium phosphate and magnesium ammonium phosphate, and chloride concentrations in buffer solutions, was not definitely found in this experiment. Accordingly, this result may not support the hypothesis of UdaLl et al. ${ }^{12,13)}$.

It is known that the urine ammonium level is increased with metabolic acidosis in ruminants ${ }^{14,15)}$. But the urine ammonium level will scarcely exceed $600 \mathrm{mg} \%$ even if the urine ammonium level would be heightened with acidosis. Therefore, the elevated ammonium level in urine may serve the forming of phosphatic urinary calculi, but will not act on the prevention or treatment of urolithiasis.

It was observed in all trials that phosphorus was more readily dissolved in buffer solutions than magnesium. This cause was not definitely known, but it was suggested that phosphorus and magnesium would not be dissolved simultaneously and magnesium phosphate and magnesium ammonium phosphate would be converted to other compounds. The conversion to other compounds may be more obvious in magnesium phosphate than in magnesium ammonium phosphate.

Among the changes of urine composition, which are induced by the administration of ammonium chloride, the decreased urine $\mathrm{pH}$ will play the most important role in the prevention of urolithiasis through increasing the solubility of phosphatic urinary calculi.

\section{References}

1) Crookshank, R. H., F.E. Keating, J.H. Jones, and R. E. Davis, J Anim Sci 19: 595-600. 1960.

2) Bushman, D.H., L. B. Embry, and R. J. Emerick, J Anim Sci 26: 1199-1204. 1967.

3) Bushman, D. H., and J.R. Embry, J Anim Sci 27: 490-496. 1968.

4) Uesaka, S., R. Kawashima, K. Namikawa, and G. Mishiro, Research Bulletin of Takahara Experimental Station in Kyoto Univ. No. 19. 1967.

5) Yano, H., R. Kawashima, and S. Uesaka, Memoirs of the College of Agric Kyoto Univ. No 101: 9-15. 1972.

6) Kaneko, J. J., and C.E. Corneluus, Clinical Biochemistry of Domestic Animals Vol. 2.52. Academic Press. New York and London. 1971.

7) Fiske, C., and Y. Subbarow, J Biol Chem 66: 375-400. 1925.

8) Johnson, R.G., J Urol 81: 681-690. 1959.

9) Elliot, J., W.Q. Robert, F. Sharp, and L. Lewis, J Urol 80: 269-271. 1958.

10) Andrews, J.E., C.L. Yarero, R. L. Golyx, and I. T. Sell, J Urol 73: 930-937. 1955. 
11) Boyce, W.H., F. K. Garvey, and C. M. Norfleet, J Urol 72: 1019-1031. 1954.

12) Udall, R. H., and F.H.C. Chow, Cornell Vet 55: 538-544. 1965.

13) Udall, R. H., C. L. Seger, and F.H.C. Chow, Cornell Vet 55: 198-203. 1965.

14) ScotT, D., F.G. Whilelaw, and M. Key, Q J1 Exp Physio 56: 16-32. 1971.

15) Scotr, D., Q JI Exp Physio 56: 33-40. 1971.

\title{
肥育牛の尿結石症防止に括ける塩北アンモン投与の作用機作
}

\author{
矢野秀 雄・川島良治 \\ 京都大学農学部, 京都市 606
}

\begin{abstract}
本試験注肥育牛の疗結石症防止に就ける塩化フンモン の作用機作を，层結石の主成分であるリン酸マダネシウ ム，リン酸マダネシウムアンモンの溶解性立通して in vitro 法で検討しょうとした。

$2 \mathrm{~g}$ のリン酸マグネシウム，リン酸マグネシウムてン モンを $300 \mathrm{~m} l$ のトリス䌅衝液中に入れ，フラスコの栓 を閉じて $39^{\circ} \mathrm{C} て ゙ 6$ 時間振とうした。， 0, 1, 2,4，6時間 目に $5 \mathrm{~m} l$ らつ各フラスコから採取して分析に倛した。 $\mathrm{pH}$ 孛低下させるとリン酸マグネシウム，リン酸マグネ シウムアンモンの溶解性は明らかに増加した。緩衝澓中 のカルシウム濃度を堌加させると上澄液中のリン濃度は
\end{abstract}

低下する傾向が見られた。この結果はカルシウムとリン の複合体の形成により生じたものと考无られた。ナトり ウム堛を緩衝液に添加するとリン酸マグネシウム, リン 酸マグネシウムフンモンの溶解性はわずかに増加した。 フンモニウム濃度が 0 から $200 \mathrm{mg} \%$ と 0 から $600 \mathrm{mg} \%$ の範国では、䌅衝液中のアンモニウム濃度が塯加するに つれてリン酸マグネシウムと，リン酸マダネシウムフン モンの溶解性はそれでれ增加の傾向があった。こ机らの 結果吕ら，塭化フンモンの疗結石症防止に対する投与教 果では，尿 $\mathrm{pH}$ の低下が鼠も大きい上うに思われた。 